This is an authors' version of a paper accepted in its definitive form by the Journal of Business Research, ( ) Elsevier, http://www.elsevier.com/wps/find/homepage.cws home and has been posted by permission of Elsevier for personal use, not for redistribution.

\title{
The Effect of Digital Signage on Shoppers' Behavior:
}

\section{The Role of the Evoked Experience}

Charles Dennis, Lincoln Business School, University of Lincoln, cdennis@lincoln.ac.uk J. Joško Brakus, Leeds University Business School, University of Leeds, J.Brakus@leeds.ac.uk

Suraksha Gupta, Brunel Business School, Brunel University, Suraksha.Gupta@brunel.ac.uk

Eleftherios Alamanos, Lincoln Business School, University of Lincoln, ealamanos@lincoln.ac.uk

The authors are grateful for comments, insights and input from TC Melewar, Middlesex University London. The authors thank the anonymous reviewers for many helpful suggestions. Send correspondence to: Charles Dennis, Lincoln Business School, University of Lincoln, Brayford Pool, Lincoln, LN6 7TS, UK (email cdennis@lincoln.ac.uk). 


\title{
The Effect of Digital Signage on Shoppers' Behavior: The Role of the Evoked Experience
}

\begin{abstract}
This paper investigates the role of digital signage as experience provider in retail spaces. The findings of a survey-based field experiment demonstrate that digital signage content high on sensory cues evokes affective experience and strengthens customers' experiential processing route. In contrast, digital signage messages high on "features and benefits" information evoke intellectual experience and strengthen customers' deliberative processing route. The affective experience is more strongly associated with the attitude towards the ad and the approach behavior towards the advertiser than the intellectual experience. The effect of an ad high on sensory cues on shoppers' approach to the advertiser is stronger for first-time shoppers, and therefore important in generating loyalty. The findings indicate that the design of brand-related informational cues broadcast over digital in-store monitors affects shoppers' information processing. The cues evoke sensory and affective experiences and trigger deliberative processes that lead to attitude construction and finally elicit approach behavior towards the advertisers.
\end{abstract}

Keywords: brand experience, shopping experience, aesthetics of experience, digital signage, store atmospherics

Article history:

Received 3 August 2012 
Received in revised form 2 May 2013

Accepted 27 April 2014 


\section{Introduction}

Shopping is not just about obtaining tangible products but also enjoyment and pleasure (Martineau, 1958), valuable benefits reflected in consumers' spending (e.g., Donovan, Rossiter, \& Marcoolyn, 1994; Jones, 1999). A practical and theoretical concern is to examine how specific design features of retail outlets stimulate consumers' enjoyment and pleasure. Previous studies examine the effects of environmental design on shoppers' responses and behavior (Chebat \& Michon, 2003; see reviews by Kaltcheva \& Weitz (2006) and by Turley \& Milliman (2000)). However, these studies focus on a limited number of atmospheric variables (e.g., scent, lighting, background music) in order to examine the extent to which consumers react affectively or cognitively (Babin, Chebat, \& Michon, 2004; Bosmans, 2006; Chebat \& Michon, 2003; Demoulin, 2011; Jang \& Namkung, 2009; Morrin \& Chebat, 2005; Morrison, Gan, Dubelaar, \& Oppewal, 2011; Walsh, Shiu, Hassan, Michaelidou, \& Beatty, 2011).

According to Schmitt (1999), retail environments can provide consumers with compelling experiences that can positively affect consumer shopping behavior, reflected by the time and money spent in the store. However, little information is known about the type of specific experiences that are evoked by atmospheric in-store elements and how these experiences affect consumers' affective and cognitive reactions as well as their approach behavior. To enrich the understanding of the processes that mediate the relationship between shoppers' experiences evoked by specific atmospheric design cues, and their in-store behavior, this study proposes an in-store response model that includes the construct of brand experience (Brakus, Schmitt, \& Zarantonello, 2009). In particular, the authors investigate how an in-store screen network — also known as Digital Signage 
(DS) - can be used as a provider of compelling experiences for shoppers that affect subsequent consumer in-store behavior. DS is a private screen network in a public place showing video (e.g., in department stores or in shopping malls). Content may include advertisements, community information, entertainment and news.

The paper focuses on the DS messages that are designed to provide shoppers with either affective or intellectual experiences (Brakus et al., 2009). Depending on the nature and the aesthetics of the evoked experience, the DS messages affect shoppers' approach behaviors either through a more deliberative route (if the evoked experience is intellectual) or through a more experiential route (if the evoked experience is affective). The analysis also addresses the effectiveness of DS as an atmospheric stimulus, and specifically the nature of experience evoked by DS and on how DS affects judgment and behavior, an area of increasing importance in marketing and in retailing (Brakus et al., 2009; Puccinelli, Goodstein, Grewal, Price, Raghubir, \& Stewart, 2009; Verhoef, Lemon, Parasuraman, Roggeveen, Tsiros, \& Schlesinger, 2009).

The work contributes to the literature on the role of design in consumer behavior (Bloch, 1995; Bloch, Brunel, \& Arnold, 2003; Holbrook \& Huber, 1979; Veryzer \& Hutchinson, 1998) by considering DS as part of service design, and the aesthetics of consumption (Schmitt \& Simonson, 1997; see also review in Venkatesh \& Meamber, 2008). The paper also empirically investigates Schmitt and Simonson's (1997) conceptual framework that focuses on brand image and aesthetics and argues that branding - at both corporate and product or service level - can be used strategically to evoke customer sensory experiences that create brand appeal and differentiate brands. 
The study takes into account both utilitarian and hedonic aspects of shopping and the corresponding information processing systems (Epstein, 1994; Loewenstein, Weber, Hsee, \& Welch, 2001). The utilitarian information processing system is examined by exposing respondents to DS messages based on cognitive, functional content. In parallel, the corresponding affect-based information processing thinking system is examined by exposing respondents to DS messages designed to contain affective, hedonic cues. In the current work, the messages are broadcast in an upscale department store in London, UK. The following section discusses how DS messages designed to evoke sensory-affective or intellectual experiences may affect shoppers' attitude and behavior.

\section{The Effectiveness of Digital Signage as an Experience Provider: Predictions}

Brand and consumer experience has become an important area of study over the last

few years (Brakus et al., 2009; Puccinelli et al., 2009; Verhoef et al., 2009). The nature of the experience construct (Brakus et al., 2009) implies that consumption activities, including shopping, must be viewed from a multidimensional perspective. Experience dimensions conceptually map happiness dimensions (Peterson, Park, \& Seligman, 2005). Specifically, evoked sensory-affective as well as behavioral experiences may contribute to "pleasure," whereas evoked intellectual experiences may contribute to "meaning." In a shopping context, this study predicts that experiences evoked by DS are - depending on their type - important contributors to shoppers' pleasure or ability for a desired purchase. A message broadcast on the in-store DS designed to contain sensory-affective cues may evoke an affective experience among customers. An inherently pleasurable experience (Dewey, 1934; Hekkert, 2006) may then positively affect shoppers' attitude and approach 
behavior. In contrast, an informational message may evoke an intellectual experience that informs consumers' in-store decision making.

The experience construct is also tied conceptually to aesthetics. The term aesthetics usually refers to sensory experiences evoked not only by arts and other visual forms (Holbrook \& Zirlin, 1985), but also by everyday objects (Forty, 1995). Hekkert (2006) suggests that the aesthetic experience is restricted to the pleasure that results from sensory perception. Therefore, at the core of an aesthetic is a pleasurable experience.

Ordinary everyday experiences have a multidimensional structure (Brakus et al., 2009; Dewey, 1922; Dewey, 1925). The dimensions include aesthetic qualities that can be perceived emotionally (Dewey, 1934). Hence, aesthetic experience is part of an everyday consumer experience like shopping. This study argues that an aesthetic experience determines consumers' response that can have more affective or cognitive elements. Note that this affect-cognition division of consumers' responses to aesthetic experiences is not considered as a dichotomy of mutually exclusive categories, but rather as a continuum. Where an individual's response falls on this continuum depends on some personal traits such as individual predisposition for aesthetic appreciation (Venkatesh \& Meamber, 2008) and on the type of evoked aesthetic experience that are empirically investigated in this study.

This consideration of the dual nature of consumer responses to different types of experiences evoked during shopping is consistent with Holbrook and Hirschman's (1982) conceptual work on consumption experiences. They distinguish between utilitarian consumption that is traditionally conceptualized as reason-based analytic problem solving, and affect-based hedonic consumption directed at the pursuit of "fantasies, 
feelings, and fun" (see also Babin, Darden, \& Griffin, 1994). In the proposed framework, intellectual experiences inform shoppers' decision making and pleasurable sensory experiences enable consumers' hedonic engagement.

Digital signage networks are relatively new retail atmospheric stimuli and their influence on in-store shopping behavior requires further research (Grewal, Ailawadi, Gauri, Hall, Kopalle, \& Robertson, 2011). The limited prior research on DS has demonstrated that shoppers welcome the information provided by DS and that they find DS networks aesthetically pleasing because they give the mall a more modern image (Newman, Dennis, \& Zaman, 2006) that reflects on consumer spending, on the frequency of visits, and on time spent in the store (Dennis, Michon, Brakus, Newman, \& Alamanos, 2012). DS also acts as an experience provider for the shoppers (Schmitt, 1999). If the broadcast message is sensory-affective (i.e., hedonic), then the evoked experience will be affective; if the broadcast message conveys functional information (i.e., the utilitarian information that is meant to help shoppers in their decision making), then the evoked experience will be intellectual. In this case the shoppers' intellectual experience consists of analytic thoughts and reasons about the advertised service or product.

Prior research has shown that brand experience has a positive impact on consumer satisfaction, stated loyalty, and brand-consumer relationship (Brakus et al., 2009; Chang $\&$ Chieng, 2006). Consumers perceive a brand as a source of compelling experiences that increase the perceived value of a brand by the consumers over and above the brand's functional and economic value (Pine \& Gilmore, 1999). When experiences lead to stimulating, pleasurable outcomes, the evoked brand experiences should affect both the past-directed satisfaction judgments and the subsequent behavior. Therefore, this study 
suggests that evoked experiences will positively affect consumers' approach behavior towards the advertiser directly (experiential route) and indirectly through the (positive) attitudes towards the ad (deliberative route).

Brand attitudes are general evaluations that are based on beliefs (Fishbein \& Ajzen, 1975), while experiences result from consumer interactions with brands or with communications of brands; for example, with ads, catalogues, packaging, shopping environments (Brakus et al., 2009; Chang \& Chieng, 2006). Brand experiences are neither belief-based nor general evaluative judgments about the brand. Rather, they include internal responses such as specific sensations, feelings, divergent (imaginative) thoughts and "approach" behaviors as well as convergent (analytical) thoughts triggered by specific brand-related stimuli (Brakus et al., 2009). Therefore most brand experiences are not cognitive in nature, except the high-order intellectual experiences such as analytical, convergent thoughts and reasons. Overall brand attitudes are more general and do not elucidate the very nature of brand experience. Nevertheless, brand experiences can result in brand evaluations and may develop into attitudes that consumers can recall when asked about their brand experiences.

Accordingly:

$H_{l a} \quad$ Digital signage ads with cognitive content (providing utilitarian information) will evoke intellectual brand experience among consumers.

$H_{1 b} \quad$ Evoked intellectual experience will be directly associated with increased approach behavior towards the advertiser.

$H_{1 c} \quad$ Evoked intellectual experience will be indirectly associated with increased approach behavior towards the advertiser by positively affecting attitude towards the ad. 
$H_{2 a} \quad$ Digital signage ads with affective content (providing hedonic information) will evoke affective brand experience among consumers.

$H_{2 b} \quad$ Evoked affective experience will be directly associated with increased approach behavior towards the advertiser.

$H_{2 c} \quad$ Evoked affective experience will be indirectly associated with increased approach behavior towards the advertiser by positively affecting attitude towards the ad.

We also suggest that a DS message designed to contain affective content, in contrast to a DS message designed to contain cognitive content, will directly result in a positive attitude towards the ad. This prediction is consistent with existing research on the effects of pleasant incidental (i.e., atmospheric) stimuli (e.g., background music, scent, lighting) on consumers' affect-mediated attitudes during a shopping trip (e.g., Bosmans, 2006; Demoulin, 2011; Morrison et al., 2011). In such a situation, consumers rely on the experiential processing system that tends to operate by default. When they process pleasant, affect-laden incidental cues consumers are unlikely to devote sufficient cognitive resources and effort to engage the deliberative system (Gorn, Goldberg, \& Basu, 1993). In a previous study examining the effects of DS the majority of respondents were unable to recall specific content (Dennis, Newman, Michon, Brakus, \& Wright, 2010). Therefore, consumers intuitively "infer" their attitude from the (positive) affect, an example of the affect-as-information heuristic (Pham, 2004; Schwarz \& Clore, 1996).

However, the study does not predict a direct association between the DS message with the cognitive, functional content and the attitude. Consumers are unlikely to engage the 
deliberative processing system to assess and reason about the incidental, functional information (e.g., features and benefits of a product or a service, attribute values) unless they are explicitly prompted to reflect on the functional information and the resulting higher-order intellectual experience. Therefore:

$\mathrm{H}_{3}$ Digital signage ads providing affective content, unlike digital signage ads providing cognitive content, will be directly associated with positive attitude towards the ad.

The primacy-of-affect effect (Pham, Cohen, Pracejus, \& Hughes, 2001) likely operates when consumers are exposed to incidental stimuli during a shopping trip (see above): $H_{4} \quad$ Evoked affective experience will be more associated with increased approach behavior towards the advertiser than will evoked intellectual experience.

In addition, although little previous research is available on which to base predictions, affective experiential elements of DS should influence the perceived hedonic value of products featured on DS (Leclerc, Schmitt, \& Dubé, 1994), strengthening the influence of the experiential route. Conversely, the intellectual elements (Brakus et al., 2009) of DS will influence the perceived utilitarian value of products featured on DS, strengthening the influence of the deliberative route:

$H_{5 a} \quad$ Cognitive digital signage content that is high on intellectual experience will strengthen the influence of the deliberative route.

$H_{5 b} \quad$ Emotional digital signage content that is high on affective experience will strengthen the influence of the experiential route. 
In short, both types of DS messages should influence consumer behavior (as argued above) and this influence will be greater for messages high on sensory and affective cues. The first contribution of this research will be to add DS as an important tool that retailers may utilize to enhance customer experience and customer spending. Second, this work should elucidate whether atmospheric stimuli such as DS should be designed to improve the intellectual experience or to increase shoppers' affective experience directly.

The next section details the method for testing the hypotheses and examining the differences in responses of the groups of consumers exposed to three different DS messages.

\section{Method}

The results are based on data gathered data at a popular retail store in London that is often visited and is also a well-known brand and a tourist destination. This high-end store enjoys a positive image and atmospherics associated with its brand name (Silva \& Alwi, 2006). A structured questionnaire investigated the process by which store atmospherics influences shoppers' cognitive and emotional evaluations (Naylor, Kleiser, Baker, \& Yorkston, 2008) and drives attitude and approach related behavior towards the advertisements broadcast on the in-store DS network and towards the advertiser. DS delivered controlled messages with specific cues that facilitated examination of cognitive and emotional responses as well as the visitors' attitudes towards the advertisement through utilitarian and hedonic evaluation paths and the influence of the messages on consumers' approach towards the advertiser. Pleasant imagery was used to provide sensory/affective experience, avoiding overtly emotional material (e.g., comedy, 
cartoons) because heterogeneity in individual tastes makes the effects of such content likely inconsistent across the whole sample. A commercial specialist produced three types of ad:

(i) High-cognitive/low affect: an ad that contains brief details and price of a tropical island holiday in mainly text form with the logo of an upscale private travel company;

(ii) High affect/low cognitive: an ad that consists of a video of a seaplane landing in a beautiful tropical lagoon next to a golden sand beach, also with the logo of the same travel company; and

(iii) High cognitive/high affect: an ad that combines the video and text from the first two ads.

The DS ads were pre-tested through a small set of individuals in order to check that they were correctly perceived as cognitive/utilitarian or emotional/hedonic respectively. Then in the main survey, interviewers at the store asked visitors if they would like to participate in the survey and briefed respondents about the research. The six constructs were: the cognitive elements of the advertisement; the emotional elements of the advertisement; utilitarian evaluations made by customers; hedonic evaluations made by customers; attitude of consumers towards the advertisement; and approach of consumers towards the advertiser. All measurement items are adopted or adapted from existing literature (Table 1). The items assessing the affective, sensory and intellectual experiences were adapted from the brand experience scale (Brakus et al., 2009) developed for product-brands as sources of experiences. However, the brand experience scale has been also successfully adapted and validated for service-brands (Chang \& 
Chieng, 2006; Skard, Nysveen, \& Pedersen, 2011; Zarantonello \& Schmitt, 2010). All scales demonstrated high reliability. The study also measured anticipated spending and number of items expected to be bought on that visit.

We investigated the process by which different advertisements influence attitude and approach related behaviors of customers towards the advertisement and the advertiser. The model tests eight causal relationships between the constructs. Figure 1 illustrates the conceptual framework.

Figure 1 here

We tested the high-cognitive/low affect, high affect/low cognitive and high cognitive/high affect ads using a between-subjects design (146, 137, and 154 respondents respectively; $\mathrm{n}=437)$.

Discriminant validity was established as average variances explained are greater than the squared correlations between variables (details available from the authors).

Table 1 here

The main demographics of sub-samples were similar (Table 2). Data was collected on various days and hours including weekdays and weekends, so that the sample was as representative as practicable of shoppers in the store. Accordingly, a number of participants recruited during weekdays were not the income-earners of their household, with home-makers, seniors and particularly students included in the sample. This is 
reflected in the relatively high proportion of non-earning (43.5 percent overall) and younger (42.3 percent under 25 overall) respondents. When respondents started the questionnaire, the DS was visible and the content loop running, including the test ad. Initially respondents answered general questions and then were asked to view the test ad. Finally, they were asked the DS questions followed by approach / avoidance questions. The results follow.

Table 2 here

\section{Results}

\subsection{Manipulation Check}

One-way ANOVA examines the differences in participants' responses to the three ads. The high-cognitive/low affect (C) and high cognitive/high affect (CwA) ads are perceived as more utilitarian than the high affect/low cognitive ad (A); and similarly the A and CwA ads are perceived as more hedonic than the $\mathrm{C}$ ad. The content significantly affects the on hedonic evaluations of the ad. Exposing shoppers to either A or $\mathrm{CwA}$ content significantly increases shoppers' hedonic evaluations of the ad (compared to C affect) but the effects of $\mathrm{A}$ and $\mathrm{CwA}$ ads are not significantly different. Similarly, the content significantly affects the utilitarian evaluations of the ad. Exposing shoppers to either $\mathrm{C}$ or CwA significantly increases shoppers' utilitarian evaluations of the ad (compared to A) but without significant difference between the effects of $\mathrm{C}$ and $\mathrm{CwA}$. Utilitarian evaluations are significantly greater than hedonic evaluations of the $\mathrm{C}$ ad. Hedonic evaluations are significantly greater than utilitarian evaluations of the A ad. Finally, 
shoppers' utilitarian and hedonic evaluations of $\mathrm{CwA}$ ad are slightly different but this difference is conceptually irrelevant (Table 3).

\section{Insert Table 3 about here}

\subsection{The Hypothesized Model}

Latent path structural equation modeling (SEM) (using IBM SPSS AMOS) tests the hypothesized model of the influence of the DS ads on shoppers' responses. In reporting the total effects of the variables,

SEM is applied three times to separate out the effects respectively of (i) the CwA ad and (ii) the $\mathrm{A}$ ad; both compared with the $\mathrm{C}$ ad; and (iii) the $\mathrm{CwA}$ ad compared with the A ad. (For brevity, the details of these separated SEMs are omitted but the results are similar to the appropriate parts of the combined model illustrated in Figure 2). The fit measures for all models satisfied all the standard criteria (Hu \& Bentler, 1999).

\section{Insert Figure 2 about here}

The results support $\mathrm{H}_{1}$ and $\mathrm{H}_{2}$ (Figure 2), with significant paths linking the digital signage ads to experience: cognitive ad to intellectual experience $\left(\mathrm{H}_{1 \mathrm{a}}\right)$ and emotional ad to affective experience $\left(\mathrm{H}_{2 \mathrm{a}}\right)$; experience to approach behavior $\left(\mathrm{H}_{1 \mathrm{~b}}\right.$ and $\mathrm{H}_{2 \mathrm{~b}}$ from intellectual experience and affective experience respectively). Indirect paths from intellectual experience $\left(\mathrm{H}_{1 \mathrm{c}}\right)$ and affective experience $\left(\mathrm{H}_{2 \mathrm{c}}\right)$ to approach behavior via attitude towards the ad are also significant. 
The direct path from the emotional ad to attitude towards the ad is a significant, yet the direct path from the cognitive ad to attitude towards the ad is non-significant, supporting $\mathrm{H}_{3}$.

The direct influence of affective experience on approach (0.53) is significantly greater than the direct influence of intellectual experience $(0.14)(\mathrm{t}=4.82 p<.001)$, demonstrating that affective experience directly influences approach behavior more than does intellectual experience. The same relationship holds if the direct and the indirect paths linking the respective experiences with approach behavior are considered. The total effect of intellectual experience on approach is $.17(.144+.133 \times .187)$. The total effect of affective experience on approach is $.63(.526+.541 \times .187+.290 \times .133 \times .187)$. These results indicate that evoked affective experience is a stronger predictor of approach behavior than evoked intellectual experience. That is to say, $\mathrm{H}_{4}$ is supported.

Finally, the cognitive ad is associated with the evoked intellectual experience, standardized coefficient $.53(\mathrm{t}=12.8, \mathrm{p}<.001)$, whereas the association between the affective ad and intellectual experience is non-significant. The affective ad is associated with the evoked affective experience, standardized coefficient $.66(t=17.0, p<.001)$, whereas the association between the cognitive ad and affective experience is nonsignificant. These results support $\mathrm{H}_{5}$.

The path from affective to intellectual experience is significant, consistent with a previously reported result that hedonic retail atmospheric stimuli could influence utilitarian evaluations (Beverland, Ching Lim, Morrison, \& Terziovski, 2006) and theoretically consistent with primacy-of-affect theory and affect-as-information heuristic (Pham et al., 2001; Schwarz \& Clore, 1996). An affective experience evoked by 
aesthetically pleasing imagery has a positive effect on higher-order utilitarian evaluations and evoked intellectual experience, exemplifying experiential and cognitive information processing systems co-working. This result is also consistent with Dewey's (1934) philosophy that aesthetics is at the core of everyday experiences.

\section{3 Differences between groups}

One-way ANOVA examines the differences between the participants who watched each ad in relation to their attitudes towards the ad, the advertiser, and the expected shopping outcomes. The findings indicate a significant effect of the content on attitude to the ad. Exposing shoppers to either A or CwA (compared to C) significantly increases attitude to

the ad; on the other hand, the difference between effects of $\mathrm{A}$ and $\mathrm{CwA}$ is non significant. The effect of the content on approach to the advertiser is also significant. Exposing shoppers to either A or CwA significantly increases approach to the advertiser (compared to $\mathrm{C})$ but the difference between effects of $\mathrm{A}$ and $\mathrm{CwA}$ is non significant. In addition, content significantly affects shopper expected spending on this trip to the store. Exposing shoppers to either A or CwA DS content significantly increases expected spending. The difference in spending between the effects of $\mathrm{A}$ and $\mathrm{CwA}$ is non significant. Finally, the effect of the content on expected number of items bought by shoppers on this trip is also significant. Exposing shoppers to either A or CwA significantly increases expected number of items bought. The difference between effects of $\mathrm{A}$ and the $\mathrm{CwA}$ is non significant (Table 4). 
Demographics have no significant influence on evoked experiences, attitudes or approach. On the other hand shoppers who visit the store for the first time (FV) and those who are non-first time visitors (NFV) are significantly different. Affective experience, Attitude to the ad, and Approach to the advertiser are significantly more positive for shoppers on their first visit. The responses to the three ads are in the expected directions for each of the groups (FV and NFV); therefore the differences in responses between the FV and NFV categories cannot affect the hypotheses testing regarding these variables (Table 5).

\section{Insert Table 5 about here}

The FV shoppers are theoretically important in this case because their motives for their first visit are likely mostly hedonic and these shoppers, unlike regular shoppers, may find aesthetic in-store experiences particularly pleasing. Therefore, the evoked sensoryaffective experiences should have a greater effect on first-time shoppers compared to regular shoppers.

Between-groups analysis investigates any moderating effect of the classification variable (i.e., $\mathrm{FV}(\mathrm{n}=165)$ compared to $\mathrm{NFV}(\mathrm{n}=250))$. At least two indicators from each latent variable are constrained equal between groups, establishing partial metric invariance $\left(\Delta \chi^{2}=13.64,7 \mathrm{df}, p \geq .05\right)$. The following items are unconstrained (measured with 1-5 rating scales): This is an affective advert; I would describe the advert (rather than the advertiser) as: ('very poor' to 'very good'); I would describe my attitude towards the advert (rather than the advertiser) as ('dislike very much' to 'like very much'); What 
do you think of the visual impact of the advert? ('very poor' to 'very good'); After viewing the advert, I will be likely to use the advertiser more often. The fit measures across groups satisfy the standard criteria: $\chi^{2}=879.6, \mathrm{df}=333, \chi 2 / \mathrm{df}=2.64, \mathrm{CFI}=.939$, $\mathrm{RMSEA}=.063$. Differences between the groups arise from the evaluation of the CwA ad; the SEM for the A ad is insignificantly variant for first $v s$. not first visit customers (structural weights $\Delta \chi^{2}=6.47,8 \mathrm{df}, p \geq .05$ ). The only significantly different structural weight in the SEM comparing the CwA with the $\mathrm{C}$ ad is the path from the dummy variable $\mathrm{CwA}$ ad to affective brand experience, significantly higher for those on their first visit (.82) compared to those not on their first visit (.57). The standardized total effect of the $\mathrm{CwA}$ ad (compared to the $\mathrm{C}$ ad) is greater for shoppers on their first visit (.55) compared to subsequent visits (.45). Therefore, the CwA ad can positively influence shoppers who are on their first visit more than others and may therefore have an important role in generating loyalty. Details of the between-groups differences are not included here in the interests of brevity but are available from the authors.

\section{Discussion}

The focus of this paper is on cognitive and sensory-affective DS contents that can provide different experiences to consumers, illuminating how DS can be used as an instore experience provider for customers. The results indicate that customers evaluate a DS message containing aesthetically pleasing sensory images more highly on affective experience than on intellectual experience because this message is able to generate a mix of entertainment and pleasure. On the other hand, the utilitarian DS message that contains text-based "features and benefits" attribute information evokes an intellectual, rather than 
an affective experience (see Figure 2). Customers find that the evoked intellectual experience gives them utilitarian value as the information received from the text-based message helps them to make decisions ( $\mathrm{H}_{1 \mathrm{a}}$ and $\mathrm{H}_{2 \mathrm{a}}$ supported).

Both types of experiences evoked by DS content - cognitive (text) or affective (video) - influence customers' construction of attitudes and subsequent behavior $\left(\mathrm{H}_{1 b, c}\right.$ and $\mathrm{H}_{2 \mathrm{~b}, \mathrm{c}}$ supported). However, evoked affective experience (Brakus et al., 2009) elicits hedonic responses (i.e., reported pleasure, feelings, sentiments, entertainment value) which, in contrast to the responses evoked by intellectual experience, are directly associated with the attitude towards the ad $\left(\mathrm{H}_{3}\right.$ supported). In addition, evoked affective experience more strongly influences attitude towards the advertisement and approach to the advertiser. In contrast, the effect of utilitarian responses (driven by the evoked intellectual experience) on attitude towards the advertisement and approach to the advertiser is low. Emotional advertisements are evaluated significantly higher than are cognitive advertisements $\left(\mathrm{H}_{4}\right.$ supported).

Regarding approach behavior, the results show the greater effectiveness of a DS ad with aesthetic content that stimulates pleasure. Evoked affective experience is a stronger predictor of approach behavior than evoked intellectual experience. Customers' experiential information processing route is also more strongly associated with constructed positive attitudes and reported approach behavior than the deliberative processing route. These findings demonstrate that DS content high on aesthetic cues that evoke affective experience, can strengthen the influence of the experiential processing route more than ads high on functional information can strengthen the influence of the deliberative processing route (H5a and $\mathrm{H} 5 \mathrm{~b}$ supported). The findings build on the 
previous literature of approach behavior that focuses more on utilitarian, "features-andbenefits" content (Morrison et al., 2011; Walsh et al., 2011).

The findings of the influence of DS ads on approach to an advertiser extend those of Dennis et al. (2012). That study examines the influence of mainly-utilitarian DS on approach behavior towards the store (spending, items bought and frequency of visits), whereas this current study demonstrates the greater influence of more emotional, hedonic content on approach to the advertiser.

Our mediation model is consistent with prior research on the 'affect-as-information' heuristic. When consumers allocate few processing resources, as seems to be the case in this study (i.e., incidental cues broadcast on an in-store DS network) they are more likely to rely on their initial affective reactions, rather than to use their higher-order cognitions such as thoughts and reasons, in construction of attitude (Pham et al., 2001). This result is consistent with the study by Dennis et al. (2010) in which most respondents were unaware of having viewed specific ads, yet still considered that the DS contributed to positive image. Taken together, the results emphasize that the evoked affective experience is at the center of the experiential processing system.

\section{Conclusions}

DS is an effective, controllable in-store experience provider. The theoretical implications of this article include that DS works by evoking specific experiences aesthetically pleasing sensory-affective or decision-helping intellectual - that then positively affect shoppers' "approach" behaviors directly and indirectly through the attitudes. Therefore, the study provides a theoretical explanation of the effectiveness of 
DS in retailing by considering DS as an experience provider and by incorporating the type of the evoked experience as a key construct of the brand experience suggested by Brakus et al. (2009) (aesthetically pleasing sensory-affective or functional intellectual). This is in contrast to the typical attitude-centric communication models suggested in previous literature (Colley, 1961; Petty \& Cacioppo, 1986; Rossiter \& Percy, 1997).

This study also enhances Schmitt and Simonson's (1997) conceptual framework concerning the role of aesthetics in marketing by demonstrating that DS can be used strategically to evoke customer sensory aesthetic experiences that then create brand appeal and brand differentiation. Finally, elaborating on Dewey's (1934) philosophical conjecture, this study suggests that shopping is an aesthetic dimension of everyday experiences.

The article also has important practical implications. The findings suggest that DS ads that evoke affective experience can be effective in increasing shoppers' intentions to buy from an advertiser and from a store that carries the DS ads. In addition, DS ads can increase the intended time spent in the store. Finally, DS ads tend to be more attractive to shoppers who are on their first visit in the store; therefore DS can enhance consumers' intentions of revisiting the store.

Future studies can address some of the limitations of this study. Future studies can recruit participants at several department stores in order to examine the behavior of a wider range of consumers, as the department store in which this study was carried out is a high-end store and many of its customers tend to have high disposable income. Finally, future studies can examine the effect of digital signage on customers of different types of 
stores (e.g. grocery stores) to examine the effect of digital signage on purchases that are part of consumers' daily routine. 


\section{References}

Babin, B. J., Chebat, J. C., \& Michon, R. (2004). Perceived appropriateness and its effect on quality, affect, and behaviour. Journal of Retailing and Consumer Services, 11, 287-298.

Babin, B. J., Darden, W. R., \& Griffin, M. D. (1994). Work and/or fun: measuring hedonic and shopping value. Journal of Consumer Research, 20, 644-656.

Beverland, M., Ching Lim, E., Morrison, M., \& Terziovski, M. (2006). In store music and consumer-brand relationships: Relational transformation following experiences of (mis)fit. Journal of Business Research, 59(9), 982-989.

Bloch, P. H. (1995). Seeking the ideal form: Product design and consumer response. Journal of Marketing, 59(3), 16-29.

Bloch, P. H., Brunel, F. F., \& Arnold, T. J. (2003). Individual differences in the centrality of visual product aesthetics: Concept and measurement. Journal of Consumer Research, 29(March), 551-565.

Bosmans, A. (2006). Scents and sensibility: when do (in)congruent ambient scents influence product evaluations? Journal of Marketing, 70(3), 32-43.

Brakus, J. J., Schmitt, B. H., \& Zarantonello, L. (2009). Brand experience: What is it? How do we measure it? And does it affect loyalty? Journal of Marketing, 73(3), 5268.

Chang, P. L., \& Chieng, M. H. (2006). Building consumer-brand relationship: A crosscultural experiential view. Psychology and Marketing, 23(11), 927-959. 
Chebat, J. C., \& Michon, R. (2003). Impact of ambient odors on mall shoppers' emotions, cognition and spending: a test of competitive causal theories. Journal of Business Research, 56(7), 529-539.

Colley, R. H. (1961). Defining advertising goals for measured advertising results. New York: Association of National Advertisers.

Demoulin, N. T. M. (2011). Music congruency in a service setting: the mediating role of emotional and cognitive responses. Journal of Retailing and Consumer Services, $18(1), 10-18$.

Dennis, C., Michon, R., Brakus, J., Newman, A., \& Alamanos, E. (2012). New insights into the impact of digital signage as a retail atmospheric tool. Journal of Consumer Behaviour, 11(6), 454-466.

Dennis, C., Newman, A., Michon, R., Brakus, J., \& Wright, L. T. (2010). The mediating effects of perception and emotion: Digital signage in mall atmospherics. Journal of Retailing and Consumer Services, 17(3), 205-215.

Dewey, J. (1922). Human nature and conduct. New York: The Modern Library.

Dewey, J. (1925). Experience and nature (Revised ed.). New York: Dover.

Dewey, J. (1934). Art as experience. New York: Penguin Publishers.

Donovan, R. J., Rossiter, J. R., Marcoolyn, G., \& Nesdale, A. (1994). Store atmosphere and purchasing behaviour. Journal of Retailing, 70(3), 283-294.

Epstein, S. (1994). Integration of the cognitive and the psychodynamic unconscious. American Psychologist, 49(8), 709-724. 
Fiore, A. M., Jin, H., \& Kim, J. (2005). For fun and profit: Hedonic value from image interactivity and responses towards an online store. Psychology and Marketing, 22(8), 669-694.

Fishbein, M., \& Ajzen, I. (1975). Belief, attitude, intention, and behavior: An introduction to theory and research. Reading, MA: Addison-Wesley.

Forty, A. (1995). Objects of desire: Design and society, 1750-1980. London: Thames and Hudson.

Gorn, G. J., Goldberg, M. E., \& Basu, K. (1993). Mood, awareness, and product evaluation. Journal of Consumer Psychology, 2(3), 237-256.

Grewal, D., Ailawadi, K. L., Gauri, D., Hall, K., Kopalle, P., \& Robertson, J. R. (2011). Innovations in retail pricing and promotions. Journal of Retailing, 87S(1), S43-S52.

Hekkert, P. (2006). Design aesthetics: principles of pleasure in design. Psychology Science, 48(2), 157-172.

Hoch, S. J., \& Ha, Y. W. (1986). Consumer Learning: Advertising and the ambiguity of product experience. Journal of Consumer Research, 13(2), 221-233.

Holbrook, M. B., \& Huber, J. (1979). Separating perceptual dimensions from affective overtones: An application to consumer aesthetics. Journal of Consumer Research, 5(4), 272-83.

Holbrook, M. B, \& Hirschman, E. C. (1982). The experiential aspects of consumption: Consumer fantasies, feelings, and fun. Journal of Consumer Research, 9(2), 132140.

Holbrook, M. B., \& Zirlin, R. B. (1985). Artistic creation, artworks, and aesthetic appreciation: Some philosophical contributions to nonprofit marketing. In R. W. 
Belk (Eds.), Advances in nonprofit marketing (pp. 1-54). Greenwich, CT: JAI Press.

Hu, L., \& Bentler, P. M. (1999). Cutoff criteria for fit indexes in covariance structure analysis: Conventional criteria versus new alternatives. Structural Equation Modeling: A Multidisciplinary Journal, 6(1), 1-55.

Jang, S. S., \& Namkung, Y. (2009). Perceived quality, emotions, and behavioral intentions: application of an extended Mehrabian-Russell model to restaurants. Journal of Business Research, 62(4), 451-460.

Jones, M. A. (1999). Entertaining shopping experiences: an exploratory investigation. Journal of Retailing and Consumer Services, 6(3), 129-139.

Kaltcheva, V., \& Weitz, B. (2006). When should a retailer create and exciting store environment? Journal of Marketing, 70(1), 107-118.

Leclerc, F., Schmitt, B. H., \& Dubé, L. (1994). Foreign branding and its effects on product perceptions and attitudes. Journal of Marketing Research, 31(2), 263-270.

Loewenstein, G. F., Weber, E. U., Hsee, C. K., \& Welch, E. S. (2001). Risk as feelings. Psychological Bulletin, 127(2), 267-286.

Martineau P. (1958). The personality of the retail store, Harvard Business Review, 36(1), $47-55$.

Morrin, S., \& Chebat, J. C. (2005). Person-place congruency: the interactive effects of shopper style and atmospherics on consumer expenditures. Journal of Service Research, 8(2), 181-191. 
Morrison, M., Gan, S., Dubelaar, C., \& Oppewal, H. (2011). In-store music and aroma influences on shopper behavior and satisfaction. Journal of Business Research, 64(6), 558-564.

Naylor, G., Kleiser, S. B., Baker, J., \& Yorkston, E. (2008). Using transformational appeals to enhance retail experience. Journal of Retailing, 84(1), 49-57

Newman, A., Dennis, C. E., \& Zaman, S. (2006). Marketing images and consumers' experiences in selling environments. Marketing Management Journal, Fall, 515599.

Peterson, C., Park, N., \& Seligman, M. E. P. (2005). Orientations to happiness and life satisfaction: the full life versus the empty life. Journal of Happiness Studies, 6, 2541.

Petty, R. E., \& Cacioppo, J. T. (1986). The elaboration likelihood model of persuasion. In L. Berkowitz (Eds.), Advances in experimental social psychology (pp. 123-205). New York: Academic.

Pham, M. T., Cohen, J. B., Pracejus, J. W., \& Hughes, G. D. (2001). Affect monitoring and the primacy of feelings in judgment. Journal of Consumer Research, 28(2), 167-188.

Pham, M. T. (2004). The logic of feeling. Journal of Consumer Psychology, 14(4), 360369.

Pine, J. B., \& Gilmore, J. H. (1999). The experience economy: Work is theatre and every business a stage. Cambridge, MA: Harvard Business School Press. 
Puccinelli, N. M., Goodstein, R. C., Grewal, D., Price, R., Raghubir, P., \& Stewart, D. (2009). Customer experience management in retailing: Understanding the buying process. Journal of Retailing, 85(1), 15-30.

Rossiter, J., \& Percy, L. (1997). Advertising communications and promotion management. (2nd ed.). New York: McGraw-Hill.

Schmitt, B., \& Simonson, A. (1997). Marketing aesthetics: The strategic management of brands,identity, and image. New York: Free Press.

Schmitt, B. (1999). Experiential marketing. Journal of Marketing Management, 15(1-3), 53-67.

Schwarz, N., \& Clore, G. L. (1996). Feelings and phenomenal experiences, In E. T. Higgins, \& A. W. Kruglanski (Eds.), Social psychology: Handbook of basic principles (pp. 433-465). New York: Guilford Press.

Silva, R. V., \& Alwi, S. F. (2006). Cognitive, affective attributes and conative, behavioural responses in retail corporate branding. Journal of Product and Brand Management, 15(5), 293-305.

Skard, S., Nysveen, H., \& Pedersen, P. E. (2011). Brand and customer experience in service organizations: Literature review and brand experience construct validation. Institute for Research in Economics and Business Administration Working Paper (No. 09/11). Retrieved from www.snf.no/Admin/Public/DWSDownload.aspx?File...WP09_11.pdf

Turley, L. W., \& Milliman, R. E. (2000). Atmospheric effects on shopping behavior: a review of the experimental evidence. Journal of Business Research, 49(2), 193-211. 
Venkatesh, A., \& Meamber, L. A. (2008). The aesthetics of consumption and the consumer as an aesthetic subject. Consumption Markets \& Culture, 11(1), 45-70.

Verhoef, P., Lemon, K., Parasuraman, A., Roggeveen, A., Tsiros, M., \& Schlesinger, L. (2009). Customer experience creation: Determinants, dynamics and management strategies. Journal of Retailing, 85(1), 31-41.

Veryzer, R. W., \& Hutchinson, J. W. (1998). The influence of unity and prototypicality on aesthetic responses to new product designs. Journal of Consumer Research, 24(4), 374-394.

Walsh, G., Shiu, E., Hassan, L. M., Michaelidou, N., \& Beatty, S. E. (2011). Emotions, store-environmental cues, store-choice criteria, and marketing outcomes. Journal of Business Research, 64(7), 737-744.

Zarantonello, L., \& Schmitt, B. H. (2010). Using the brand experience scale to profile consumers and predict consumer behaviour. Journal of Brand Management, 17(7), $532-540$. 
Table 1: Measurement Scales

\section{Dimensions and Items}

Adopted/adapted from

Intellectual brand experience (utilitarian). $\alpha=.97 ; \mathrm{CR}=.96$

$(\alpha:=.84 ; C R=.83)$

If I were planning to buy a holiday, the advert would help me to make a better

Fiore et al., (2005); Hoch \& Ha (1986)

decision

Viewing the advert provides information that would be helpful in buying a holiday

If I were planning to buy a holiday, the advert would help me to find what I was looking for

Viewing the advert gives me more information about holidays and travel

Babin et al., (1994); Fiore et al., (2005);

Newman et al., (2006)

If I were planning to buy a holiday, the advert would help me to find what I was

Babin et al., (1994)

looking for

The advert stimulates my problem solving ${ }^{1}$

Brakus et al., (2009)

I engage in a lot of thinking when I encounter an advert like this one ${ }^{1}$

Viewing the content about the travel agent would provide utilitarian value (practical

or functional) if I were planning to buy a holiday ${ }^{1}$

Fiore et al., (2005); Hoch \& Ha (1986)

Babin et al., (1994)

Brakus et al., (2009)

Holbrook \& Hirschman (1982); Leclerc et

al., (1994)

Affective brand experience (hedonic). $\alpha=.97 ; \mathrm{CR}=.96$

$(\alpha:=.94 ; C R:=.90)$

Viewing the advert provides entertainment

Dennis et al., (2010)

Viewing the advert is pleasurable

Dennis et al., (2010); Leclerc et al., (1994)

The advert induces feelings and sentiments

Brakus et al., (2009)

This is an affective advert

Brakus et al., (2009)

Viewing this content is truly a joy ${ }^{2}$

Babin et al., (1994)

Viewing this content felt like an escape ${ }^{2}$

Babin et al., (1994)

I enjoyed viewing this content for its own sake, not just for the items I may purchase ${ }^{2}$

Babin et al., (1994)

When viewing this content, I enjoyed being immersed in an exciting new holiday ${ }^{2}$

Babin et al., (1994)

Viewing this advert whilst shopping is a very nice time out ${ }^{2}$

Babin et al., (1994)

Attitude towards the DS advert. $\alpha=.93 ; \mathrm{CR}=.93$

What do you think of the sensory appeal of the advert?

Brakus et al., (2009) 
What do you think of the visual impact of the advert?

I would describe the advert (rather than the advertiser) as: (very poor - very good)

I would describe my attitude towards the advert (rather than the advertiser) as: (dislike very much - like very much)

I would describe the advert (rather than the advertiser) as: very commonplace - very distinctive

Viewing the content affects my shopping trip in a ... way (very negative - very positive $)^{3}$

Viewing the content motivates me to search for a specific product or service in the store $^{3}$

\section{Advertiser avoidance / approach. $\alpha=.95 ; \mathrm{CR}=.92$}

$(\alpha: .93 ; C R:=.92)$

After viewing the advert, I will be likely to use the advertiser more often

After viewing the advert, I am more interested in the advertiser than I was previously

The advert enhances my feelings towards the advertiser

After viewing the advert, I would describe my attitude towards the advertiser (rather than the advert) as; (dislike very much - like very much)

After viewing the advert, if I were planning to buy a holiday I would be more likely to book with the advertiser ${ }^{1}$

After viewing the content, I am likely to spend more money on travel requirements with that travel agent ${ }^{1}$
Brakus et al., (2009)

Leclerc et al., (1994)

Dennis et al., (2010); Leclerc et al., (1994)

Newman et al., (2006)

Leclerc et al., (1994)

Newman et al., (2006)
Donovan et al., (1994)

Donovan et al., (1994)

Brakus et al., (2009)

Leclerc et al., (1994)

Leclerc et al., (1994)

Chebat \& Michon (2003); Dennis et al.,

Notes. Five-point Likert (anchored by disagree strongly - agree strongly) or semantic differential scales.

$\alpha=$ Cronbach alpha, $\mathrm{CR}=$ Composite reliability $($ Pretest $)$

Discriminant validity was established as average variances explained are greater than the squared correlations between variables (details available from the authors).

${ }^{1}$ Item dropped from the analysis of the pretest.

${ }^{2}$ Item not included in the main study questionnaire.

${ }^{3}$ Item dropped from the analysis of the main study.

${ }^{4}$ Discriminant validity was established as average variances explained are greater than the squared correlations between variables (details available from the authors). 
Table 2: Sample Characteristics for the Main Study

\begin{tabular}{|c|c|c|c|c|c|}
\hline & $\begin{array}{l}\text { High- } \\
\text { cognitive/low } \\
\text { affect }\end{array}$ & $\begin{array}{l}\text { High } \\
\text { affect/low } \\
\text { cognitive }\end{array}$ & $\begin{array}{l}\text { High } \\
\text { cognitive/high } \\
\text { affect }\end{array}$ & Overall & $\begin{array}{l}\text { Pearson } \chi^{2} \\
(2 d f) p\end{array}$ \\
\hline Percent female & 66.4 & 55.5 & 63.6 & 62.0 & .144 \\
\hline Age: percent up to 25 years & 38.4 & 42.3 & 46.1 & 42.3 & .40 \\
\hline Based in UK & 44.5 & 41.6 & 42.9 & 43.0 & .88 \\
\hline Percent income-earning & 52.7 & 52.6 & 63.6 & 56.5 & .086 \\
\hline
\end{tabular}


Table 3: Manipulation check.

\section{Means ANOVA T-Test}

\begin{tabular}{|c|c|c|c|}
\hline \multicolumn{4}{|c|}{ Content of the advertisement } \\
\hline \multirow[t]{3}{*}{ Utilitarian Evaluations } & $\mathrm{M}_{\mathrm{C}}=3.22$ & $\mathrm{~F}(2,434)=55.3 * * *$ & $\mathrm{C}$ or $\mathrm{CwA}-\mathrm{A}: \mathrm{t}(434)=4.41 * * *$ \\
\hline & $\mathrm{M}_{\mathrm{CwA}}=3.36$ & & $\mathrm{C}-\mathrm{CwA}: \mathrm{t}(434)=1.06 n s$ \\
\hline & $\mathrm{M}_{\mathrm{A}}=2.10$ & & \\
\hline \multirow[t]{3}{*}{ Hedonic Evaluation } & $\mathrm{M}_{\mathrm{C}}=1.77$ & $\mathrm{~F}(2,434)=161.6 * * *$ & $\mathrm{~A}$ or $\mathrm{CwA}-\mathrm{C}: \mathrm{t}(378)=19.9 * * * \#$ \\
\hline & $\mathrm{M}_{\mathrm{A}}=3.54$ & & A - CwA: $\mathrm{t}(378)=-.02 n s \#$ \\
\hline & $\mathrm{M}_{\mathrm{CwA}}=3.53$ & & \\
\hline \multicolumn{4}{|l|}{$\mathrm{C}$ ad } \\
\hline Utilitarian Evaluation & $\mathrm{M}_{\mathrm{C}}=3.22$ & & $\mathrm{t}(145)=14.8 * * *$ \\
\hline Hedonic Evaluation & $\mathrm{M}_{\mathrm{C}}=1.77$ & & \\
\hline \multicolumn{4}{|l|}{ A ad } \\
\hline Utilitarian Evaluation & $\mathrm{M}_{\mathrm{A}}=2.10$ & & $\mathrm{t}(136)=12.2 * * *$ \\
\hline Hedonic Evaluation & $\mathrm{M}_{\mathrm{A}}=3.54$ & & \\
\hline \multicolumn{4}{|l|}{ CwA ad } \\
\hline Utilitarian Evaluation & $\mathrm{M}_{\mathrm{CwA}}=3.36$ & & $\mathrm{t}(153)=2.2 *$ \\
\hline Hedonic Evaluation & $\mathrm{M}_{\mathrm{CwA}}=3.53$ & & \\
\hline
\end{tabular}

Note: Utilitarian and Hedonic Value 1-5 composite scales, higher numbers more utilitarian or hedonic respectively.

Approach to advertiser 1-5 composite scale, higher numbers stronger intention to approach.

T-tests based on planned contrasts to avoid inflating family-wise error.

\# df adjusted so as not to assume equal variance in the case where the Levine statistic is significant.

$n s=p>.05 ; *=p<.05 ; * * *=p<.001$. 
Table 4: Effect of ad content

\begin{tabular}{|c|c|c|c|}
\hline & Means & $A N O V A$ & T-Test \\
\hline Attitude towards ad\# & $\begin{array}{l}\mathrm{M}_{\mathrm{C}}=2.52 \\
\mathrm{M}_{\mathrm{A}}=3.12 \\
\mathrm{M}_{\mathrm{CwA}}=3.08\end{array}$ & $\mathrm{~F}(2,434)=46.9 * * *$ & $\begin{array}{l}\mathrm{A} \text { or } \mathrm{CwA}-\mathrm{C}: \mathrm{t}(434)=9.69 * * * \\
\mathrm{~A}-\mathrm{CwA}: \mathrm{t}(434)=-.29 n s\end{array}$ \\
\hline Approach to advertiser\# & $\begin{array}{l}\mathrm{M}_{\mathrm{C}}=2.21 \\
\mathrm{M}_{\mathrm{A}}=3.99 \\
\mathrm{M}_{\mathrm{CwA}}=4.05\end{array}$ & $\mathrm{~F}(2,434)=171.1 * * *$ & $\begin{array}{l}\text { A or CwA - C: } t(434)=16.8 * * * \\
\text { A - CwA: } t(434)=.71 n s\end{array}$ \\
\hline Expected spending\#\# & $\begin{array}{l}\mathrm{M}_{\mathrm{C}}=2.39 \\
\mathrm{M}_{\mathrm{A}}=2.71 \\
\mathrm{M}_{\mathrm{CwA}}=2.67\end{array}$ & $\mathrm{~F}(2,434)=3.275^{*}$ & $\begin{array}{l}\mathrm{A} \text { or } \mathrm{CwA}-\mathrm{C}: \mathrm{t}(434)=2.55 * * \\
\mathrm{~A}-\mathrm{CwA}: \mathrm{t}(434)=-.29 n \mathrm{~s}\end{array}$ \\
\hline $\begin{array}{c}\text { Expected number of items } \\
\text { bought\#\# }\end{array}$ & $\begin{array}{l}\mathrm{M}_{\mathrm{C}}=2.90 \\
\mathrm{M}_{\mathrm{A}}=4.07 \\
\mathrm{M}_{\mathrm{CwA}}=4.51\end{array}$ & $\mathrm{~F}(2,434)=3.53 *$ & $\begin{array}{l}\text { A or CwA }-C: t(434)=2.53 * \\
A-C w A: t(434)=.72 n s\end{array}$ \\
\hline
\end{tabular}

\#1-5 composite scales.

\#\#1-5 scales with coding redacted for commercial confidentiality.

T-tests based on planned contrasts to avoid inflating family-wise error.

$n s=\mathrm{p}>.05 ; *=\mathrm{p}<.05 ; * *=\mathrm{p}<.01 ; * * *=\mathrm{p}<.001$. 
Table 5: Mean differences for first visit vs. not first visit to the store

\begin{tabular}{llll}
\hline & First Visit & Not First Visit & Differences between Groups \\
\hline Affective Experience\# & $\mathrm{M}_{\mathrm{FV}}=3.3$ & $\mathrm{M}_{\mathrm{NFV}}=2.8$ & $\mathrm{t}(413)=4.2^{* *}$ \\
& & & \\
Attitude towards ad\# & $\mathrm{M}_{\mathrm{FV}}=3.8$ & $\mathrm{M}_{\mathrm{NFV}}=3.4$ & $\mathrm{t}(413)=4.5^{* *}$ \\
& & & $\mathrm{t}(413)=3.7^{* *}$ \\
Approach to & $\mathrm{M}_{\mathrm{FV}}=3.1$ & $\mathrm{M}_{\mathrm{NFV}}=2.7$ & \\
advertiser\# & & & \\
\hline
\end{tabular}

\#1-5 composite scales.

$\mathrm{ns}=\mathrm{p}>.05 ; *=\mathrm{p}<.05 ; * *=\mathrm{p}<.01 ; * * *=\mathrm{p}<.001$.

The Bonferroni correction to control for family-wise error has been applied to amend the $\mathrm{p}$ values to equivalents based on five post hoc variables 
Figure 1: Schematic Illustration of Hypothesized Model

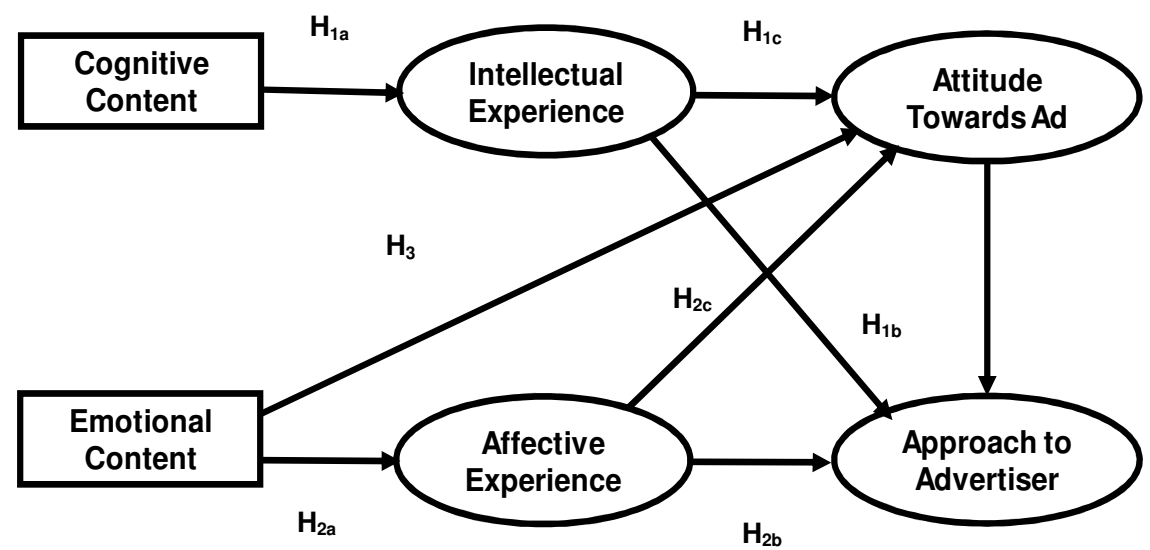


Figure 2: Latent Path Analysis

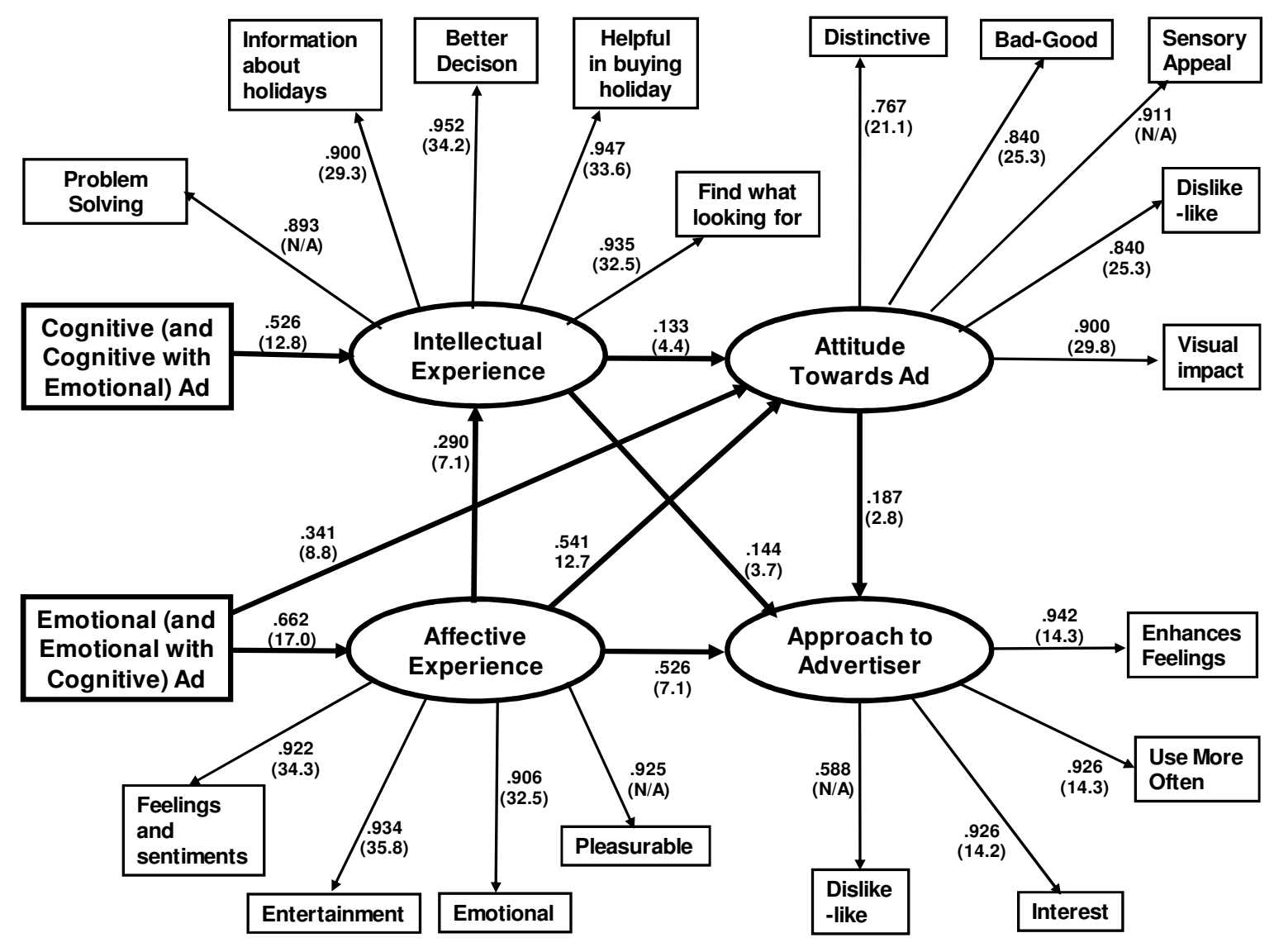

Standardized coefficients (t-value)

Method: $\mathrm{ML} ; \chi^{2}=667.6, \mathrm{df}=163, \chi 2 / \mathrm{df}=4.1, \mathrm{CFI}=.946, \mathrm{RMSEA}=.084$ 